\title{
Analisis Pengaruh Mental Blocking Terhadap Berpikir Analitis Dan Kritis Dalam Kegiatan Promosi
}

\author{
Dimas Perdana Oskar, Andhika Anggawira \\ Universitas Putra Indonesia YPTK Padang, Indonesia \\ * E-mail: dimasperdanaoskar@upiyptk.ac.id
}

\begin{abstract}
Failure in promotional activities if not well managed will make business people in some condition that is known as mental blocking. This research design is descriptive research into secondary data with cross sectional approach which was held to understand the impact of mental blocking toward analytical and critical thinking in micro and small enterprise promotion activities. This research location was in Padang by collecting 229 research questionnaires from micro and small business women from July $28^{\text {th }} 2020$ to August $7^{\text {th }} 2020$ with 5\% error rate. We can conclude that there was negative relationship between mental blocking and analytical and critical thinking with $\mathrm{R}-0.62$. On the same hand, this research finding is that mental blocking have no significant impact toward analytical and critical thinking where $\mathrm{R}^{2}$ is 4 percent. This was due to majority in scoring distribution of mental blocking aspect were in low level while majority in scoring distribution of analytical and critical thinking in higher level. This study suggested that future researcher must simplified the research scale and deeper analysis in finding other variable.
\end{abstract}

Kata kunci: business woman, mental blocking, promotion

\section{Pendahuluan}

Dalam pembangunan ekonomi di Indonesia, UMKM selalu digambarkan sebagai sektor yang mempunyai peranan penting, karena sebagian besar jumlah penduduknya berpendidikan rendah dan hidup dalam kegiatan usaha kecil baik di sektor tradisional maupun modern. [1] Untuk mengembangkan UMKM yang ada di Indonesia, berbagai kegiatan dan program pun dilaksanakan oleh Pemerintah pusat dan daerah. Dalam Undang-undang No. 20 tahun 2008 tentang usaha Mikro, Kecil dan Menengah menyatakan bahwa pemerintah pusat dan daerah bersama-sama memberdayakan dan mengembangkan UMKM yang ada.

Dari data Badan Pusat Statistik (BPS) Nasional di tahun 2016, jumlah UMKM yang ada di Indonesia mencapai 56,5 juta unit dengan tingkat serapan tenaga kerja rata - rata yakni sebesar $2-3$ tenaga kerja pada masing-masing UMKM. Jumlah korporasi di Indonesia hanya sebanyak 8,000 unit yang artinya jumlah UMKM yang ada di Indonesia mendekati 99,9\%.[2] Provinsi Sumatera Barat memiliki jumlah UMKM yang cukup tinggi. Jumlah Usaha Mikro, Kecil dan Menengah di Provinsi Sumatra Barat di dominasi oleh Kota Padang. Terdapat kurang lebih sekitar 40,353 unit Usaha Mikro Kecil di Kota Padang dari jumlah keseluruhan pertumbuhan Usaha Mikro Kecil di Provinsi Sumatra Barat mencapai 114,538 unit usaha.[3] Berdasarkan jumlah Usaha Mikro Kecil tersebut maka peneliti mengambil penelitian di Kota Padang dikarenakan Kota Padang merupakan daerah dengan jumlah Usaha Mikro Kecil terbanyak dibandingkan Kota/Kabupaten di Provinsi Sumatra Barat dan Kota Padang merupakan gerbang utama masuknya wisatawan dalam dan luar negeri.[4]

Data statistik berdasarkan pemilah jenis kelamin tidak diterapkan di Indonesia yang mengarah pada kurangnya bukti nyata tentang proporsi pengusaha wanita dalam Usaha Mikro Kecil dan Menengah dan kontribusi mereka dalam perekonomian nasional. Dari data survey pasar yang dilakukan oleh World Bank pelaporan Maret 2016 menyatakan bahwa saat ini wanita pelaku Usaha Mikro Kecil di Indonesia diperkirakan sebanyak 43\% dari total usaha yang ada pada saat 
ini.[5] Dengan asumsi berdasarkan penjabaran diatas maka diperkirakan saat ini ada sekitar 17,400 wanita pelaku Usaha Mikro Kecil di Kota Padang.

Fitriyani menyebutkan bahwa mental block adalah cara berpikir dan perasaan yang terhalang oleh adanya ilusi-ilusi pikiran.[6] Sedangkan menurut Pattinson dan Cotterill [7], mental block disebabkan oleh ketidaksiapan seseorang dalam menghadapi perubahan, meningkatnya level kompetisi, tekanan orang tua dan pelatih, kurangnya skill dan kecemasan. Dirangkum dari berbagai sumber berbasis online, ada beberapa hal yang menyebabkan terjadinya proses mental block pada seseorang yakninya: (1) Menterjemahkan sebuah permasalahan terlalu sempit, (2) Mengasumsikan bahwa hanya ada satu jawaban dari setiap pertanyaan, (3) Terpapar oleh terlalu banyaknya informasi yang tidak diperlukan dalam pengambilan keputusan atau disebut juga mental dazzle, (4) Tertekan akan tidak kunjung berhasil, dan (5) Cemas akan sebuah keberhasilan.

Berpikir analitis adalah berusaha mengenal sesuatu dengan dengan cara mengenali ciri-ciri atau unsur-unsur yang ada pada suatu itu. Berpikir analitis mengharuskan kita untuk berpikir secara berhati - hati dengan terlebih dahulu membagi - bagi masalah yang dihadapi untuk kemudian mencarikan sebuah kesimpulan atas permasalahan yang ada dalam pemecahan masalah tersebut.[8] Berpikir kritis adalah sebuah proses yang digunakan untuk mengevaluasi alternatif, membuat penilaian berdasarkan alasan yang kuat, atau membuktikan kebenaran posisi, sikap, serta sudut pandang. Penelitian ini juga menyebutkan bahwa ada syarat yang diperlukan untuk memiliki kemampuan berpikir kritis yaitu sikap untuk menggunakan pemikiran yang dalam di dalam melihat suatu pengetahuan tentang metode untuk bertanya dan mengemukakan alasan dengan logis.[9] Sedangkan di dalam Jurnal Edukasi Vol. I No. 2 tahun 2015 [10] menyebutkan kriteria dari berpikir kritis adalah interpretation, analysis, inferensi, evaluation, explanation, dan self-regulation.

Berpikir kritis adalah proses kemampuan siswa untuk mengidentifikasi asumsi yang digunakan; merumuskan pokok - pokok permasalahan; menentukan akibat dari suatu ketentuan yang diambil; mendeteksi ada nya bias berdasarkan pada sudut pandang yang berbeda; mengungkap konsep, teorema atau definisi yang digunakan; serta mengevaluasi argumen yang relevan dalam menyelesaikan suatu masalah.[11] Keterampilan untuk menerapkan metode tersebut menyatakan bahwa berpikir kritis adalah suatu kemampuan berpikir yang sudah melibatkan proses analisa, evaluasi dan dapat dipertanggungjawabkan. Dapat kita simpulkan bahwa berpikir kritis merupakan sebuah proses berpikir dalam menganalisa dan mngevaluasi paparan informasi yang didapatkan seseorang untuk membuat sebuah keputusan.

Berbicara tentang promosi harus dimulai dengan mengenali terlebih dahulu bahwa promosi merupakan bagian dari komunikasi pemasaran. Komunikasi pemasaran adalah suatu alat yang digunakan oleh sebuah usaha / pelaku usaha yang dimaksudkan untuk menginformasikan, membujuk, dan mengingatkan konsumen baik secara langsung atau tidak langsung tentang produk dan merek yang mereka tawarkan.[12] Dalam Kotler dan Keller [13] bauran kegiatan promosi yang terintegrasi yang disebut juga bauran komunikasi pemasaran yang mana setiap kategori haruslah mampu menjalin sebuah komunikasi dengan konsumen yang dituju, terdiri atas: (1) Periklanan, (2) Promosi penjualan, (3) Penjualan personal, (4) Hubungan masyarakat, dan (5) Pemasaran langsung.

Dalam kegiatan promosi yang dilakukan para pelaku usaha UMKM, kegagalan yang ditimbulkan oleh para pelaku UMKM bisa membawa dirinya masuk dalam suatu kondisi pikiran maupun perasan yang mengalami hambatan (mental block). Hadirnya mental block ini membuat kemampuan analitis dan kemampuan kritis seseorang mengalami gangguan, sehingga membuat orang tersebut sulit melakukan analisa dan mengkritisi suatu situasi dan kondisi dikarenakan kemunculan mental block ini membuat seseorang merasa tidak mampu melakukan hal apapun, 
bahkan di saat seseorang mengerjakan ide promosi yang ia miliki, orang tersebut bisa saja mengalami mental blocking yang membuat ide promosinya tidak bisa direalisasikan. Adapun bagan dari hubungan pengaruh mental block terhadap berpikir analitis dan kritis dalam kegiatan promosi dapat dijelaskan sebagai berikut:

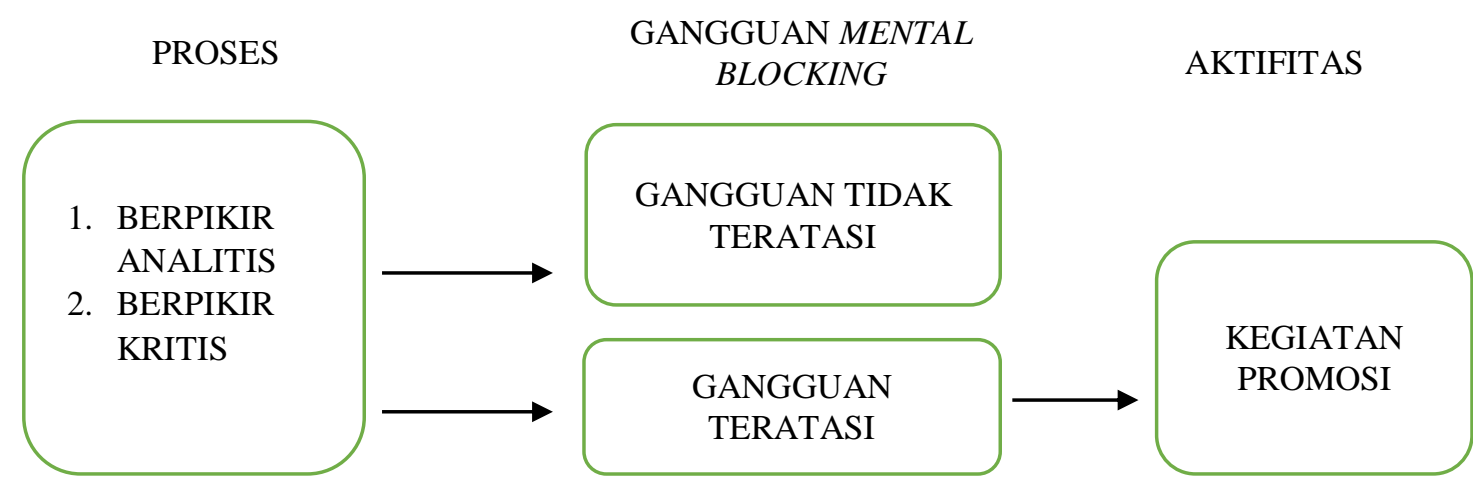

Gambar 1: Mental blocking, Berpikir Analitis, Berpikir Kritis, dan Promosi (Oskar dan Anggawira, 2019)

Dari gambar diatas dapat kita lihat bahwa berpikir analitis dan kritis yang dialami oleh para wanita pelaku usaha dalam kegiatan promosi usaha mereka apakah mempengaruhi gangguan yang akan muncul dan kemampuan mereka untuk mengatasinya yang disebut dengan mental blocking.

Sesuai dengan perumusan masalah, maka tujuan yang ingin diwujudkan melalui penelitian ini adalah untuk mengetahui seberapa besar pengaruh mental blocking terhadap berpikir analitis dan kritis dalam kegiatan promosi yang dilakukan oleh wanita pelaku Usaha Mikro Kecil.

\section{Metodologi Penelitian}

Pendekatan yang digunakan dalam penelitian ini adalah pendekatan kuantitatif, karena data yang didapat memungkinkan digunakan teknik analisis statistik. Menurut Sugiyono [14] metode penelitian kuantitatif dapat diartikan sebagai metode penelitian yang berdasarkan pada filsafat positivisme, digunakan untuk meneliti pada populasi atau sampel tertentu. Desain penelitiannya adalah penelitian deskriptif terhadap data sekunder yaitu untuk mengetahui pengaruh mental blocking terhadap berpikir analitis dan kritis dalam kegiatan promosi dari wanita pelaku usaha mikro kecil dengan pendekatan cross sectional yakni studi yang sifatnya mengambil sampel dari populasi - populasi pada satu titik waktu yang sama.[15] Lokasi penelitian ini dilakukan di Kota Padang dengan mendatangi wanita pelaku Usaha Mikro Kecil dan dinas terkait guna mengumpulkan data penelitian. Pengumpulan data penelitian dilakukan dari tanggal 28 Juli 2020 sampai dengan tanggal 7 Agustus 2020. Dalam Sevilla [16] teknik pengambilan sampel yang digunakan adalah purposive sampling dengan kriteria (1) jenis kelamin wanita, (2) pelaku usaha mikro (memiliki hasil penjualan tahunan paling banyak Rp300.000.000) dan usaha kecil (memiliki hasil penjualan tahunan lebih dari Rp300.000.000 sampai dengan paling banyak Rp2.500.000.000)[17] dan (3) berada di Kota Padang, sedangkan untuk jumlah sampel sendiri menggunakan penyederhanaan dari Rumus Lemeshow atau disebut juga Rumus Slovin dengan tingkat kesalahan 5\%. Data dalam penelitian ini bersumber dari hasil pengisian skala yang diisi oleh wanita pelaku Usaha Mikro Kecil di Kota Padang sebanyak 229 kuesioner. Instrumen dalam penelitian ini menggunakan lembar kuesioner dan skala likert untuk skala berpikir analitis dan kritis yang diadaptasi dari Mustafa [18] dengan nilai reliabilitas .846 sebanyak 20 pertanyaan serta skala indikator variabel mental blocking dengan menggunakan lembar 
kuesioner dan skala likert yang diadaptasi dari Fitriyani [19] yakninya indikator blame (menyalahkan), indikator excuse (beralasan), indikator lazy (malas), indikator afraid (takut), indikator waiting (menunggu), indikator unconfident (tidak percaya diri), dan indikator bad suspicion (buruk sangka) sebanyak 36 pertanyaan dan setelah dilakukan uji butir didapatkan nilai reliabilitas .908 dari 24 item pertanyaan yang tersisa.

\section{Hasil dan Pembahasan}

Deskripsi statistik pada bab ini akan menyajikan informasi data pada masing-masing variabel meliputi distribusi frekuensi dan kategorisasi hasil pengukuran. Pendeskripsian masing-masing variabel secara rinci sebagai berikut.

\subsection{Data Berpikir Kritis dan Analitis}

Tabel 1: Distribusi Frekuensi Skala Berpikir Kritis dan Analitis

\begin{tabular}{cccc}
\hline $\begin{array}{c}\text { Tingkat Berpikir } \\
\text { Kritis dan } \\
\text { Analitis }\end{array}$ & Indikator & N & Persentase (\%) \\
\hline Kurang & $81-86$ & 2 & $0.87 \%$ \\
Cukup & $87-93$ & 219 & $95.63 \%$ \\
\hline Baik & $94-100$ & 8 & $3.50 \%$ \\
\hline Jumlah & & $\mathbf{2 2 9}$ & $\mathbf{1 0 0}$ \\
\hline
\end{tabular}

Dari tabel diatas terungkap bahwa 95,63\% dari keseluruhan subjek memiliki tingkat berpikir analitis dan kritis di tingkat yang cukup. Dapat kita artikan bahwa subjek memiliki pemahaman yang cukup dalam melakukan proses kegiatan promosi bagi produk yang mereka miliki. Hal ini dapat diukur dari skala yang disebarkan dalam penelitian.

Tabel 2: Distribusi Frekuensi Aspek Merumuskan Masalah pada Skala Berpikir Kritis dan Analitis

\begin{tabular}{cccc}
\hline $\begin{array}{c}\text { Tingkat Berpikir } \\
\text { Kritis dan } \\
\text { Analitis }\end{array}$ & Indikator & N & Persentase (\%) \\
\hline Kurang & $6-9$ & 12 & $5.24 \%$ \\
Cukup & $10-12$ & 168 & $73.36 \%$ \\
\hline Baik & $13-15$ & 49 & $21.40 \%$ \\
\hline Jumlah & & $\mathbf{2 2 9}$ & $\mathbf{1 0 0}$
\end{tabular}

Dari tabel di atas diketahui bahwa mayoritas dari subjek pada aspek merumuskan masalah berada pada tingkat cukup dimana terdapat 168 responden memahami dengan jelas langkah langkah yang mereka lakukan dalam melakukan proses kegiatan promosi usahanya.

Tabel 3: Distribusi Frekuensi Aspek Menganalis pada Skala Berpikir Kritis dan Analitis

\begin{tabular}{cccc}
\hline $\begin{array}{c}\text { Tingkat Berpikir } \\
\text { Kritis dan } \\
\text { Analitis }\end{array}$ & Indikator & N & Persentase (\%) \\
\hline Kurang & $11-14$ & 16 & $6.99 \%$ \\
Cukup & $15-17$ & 97 & $42.36 \%$ \\
Baik & $18-20$ & 116 & $50.65 \%$ \\
\hline Jumlah & & 229 & $\mathbf{1 0 0}$ \\
\hline
\end{tabular}


Pemahaman responden dalam analisis skala berpikir kritis dan analisis untuk memahami permasalahan dan kendala mereka dalam merumuskan strategi dalam proses kegiatan promosi dinilai sangat baik. Dapat kita lihat, lebih dari 50 persen responden berada pada tingkat analisa yang baik.

Tabel 4: Distribusi Frekuensi Aspek Melakukan Evaluasi pada Skala Berpikir Kritis dan Analitis

\begin{tabular}{cccc}
\hline $\begin{array}{c}\text { Tingkat Berpikir } \\
\text { Kritis dan } \\
\text { Analitis }\end{array}$ & Indikator & N & Persentase (\%) \\
\hline Kurang & $9-12$ & 4 & $1.75 \%$ \\
Cukup & $13-16$ & 69 & $30.13 \%$ \\
Baik & $17-2$ & 156 & $68.12 \%$ \\
\hline Jumlah & & 229 & $\mathbf{1 0 0}$ \\
\hline
\end{tabular}

Responden dalam mengevaluasi kegiatan promosi yang telah mereka lakukan berada pada tingkat analisis yang baik dengan persentase $68.12 \%$. Artinya adalah para wanita pelaku usaha mikro dan kecil tersebut memiliki pengetahuan yang baik dalam melakukan evaluasi kegiatan promosi. Dalam arti lain, para wanita pelaku usaha tersebut sudah paham keuntungan yang akan mereka dapatkan dari kegiatan promosi usaha mereka.

Tabel 5: Distribusi Frekuensi Aspek Terbuka Terhadap Kemungkinan pada Skala Berpikir Kritis dan Analitis

\begin{tabular}{cccc}
\hline $\begin{array}{c}\text { Tingkat Berpikir } \\
\text { Kritis dan } \\
\text { Analitis }\end{array}$ & Indikator & N & Persentase (\%) \\
\hline Kurang & $13-15$ & 30 & $13.10 \%$ \\
Cukup & $16-18$ & 149 & $65.07 \%$ \\
Baik & $19-20$ & 50 & $21.83 \%$ \\
\hline Jumlah & & 229 & $\mathbf{1 0 0}$ \\
\hline
\end{tabular}

Dari tabel di atas diketahui bahwa mayoritas dari subjek pada aspek terbuka terhadap kemungkinan berada pada tingkat cukup. Para wanita pelaku usaha ini memiliki pemikiran yang cukup terbuka untuk mencoba hal baru dalam kegiatan promosi usaha mereka.

Tabel 6: Distribusi Frekuensi Aspek Mengungkapkan sesuatu berdasarkan fakta pada Skala Berpikir Kritis dan Analitis

\begin{tabular}{cccc}
\hline $\begin{array}{c}\text { Tingkat Berpikir } \\
\text { Kritis dan } \\
\text { Analitis }\end{array}$ & Indikator & N & Persentase (\%) \\
\hline Kurang & $14-17$ & 6 & $2.62 \%$ \\
Cukup & $18-21$ & 89 & $38.86 \%$ \\
Baik & $22-25$ & 134 & $58.52 \%$ \\
\hline Jumlah & & 229 & $\mathbf{1 0 0}$ \\
\hline
\end{tabular}

Para responden dengan baik mampu memilah fakta yang mereka hadapi dalam kegiatan promosi. Pemilahan fakta ini sangat penting sehingga keputusan yang akan mereka ambil berdasarkan fakta bukan sekedar asumsi. 


\subsection{Mental Blocking}

Tabel 7: Distribusi Frekuensi Mental Blocking

\begin{tabular}{cccc}
\hline $\begin{array}{c}\text { Tingkat Mental } \\
\text { Blocking }\end{array}$ & Indikator & N & Persentase (\%) \\
\hline Rendah & $60-74$ & 133 & $58.08 \%$ \\
Sedang & $75-104$ & 87 & $37.99 \%$ \\
Tinggi & $105-120$ & 9 & $3.93 \%$ \\
\hline Jumlah & & $\mathbf{2 2 9}$ & $\mathbf{1 0 0}$ \\
\hline
\end{tabular}

Frekwensi mental blocking dari para wanita pelaku usaha sebagai responden dalam penelitian ini sangat rendah yang berada di angka 58.08\%. Hal ini dapat diartikan bahwa mayoritas responden sangat siap dalam mengahadapi pemikiran - pemikiran yang mampu mengahalangi mereka dalam melakukan kegiatan promosi usaha. Hal memiliki arti yang positif dalam pengembangan mental dari wanita pelaku usaha dalam kegiatan promosi.

Tabel 8: Distribusi Frekuensi Mental Blocking pada aspek Blame

\begin{tabular}{cccc}
\hline $\begin{array}{c}\text { Tingkat Mental } \\
\text { Blocking }\end{array}$ & Indikator & N & Persentase (\%) \\
\hline Rendah & $6-8$ & 20 & $8.73 \%$ \\
Sedang & $9-12$ & 188 & $82.10 \%$ \\
Tinggi & $13-15$ & 21 & $9.17 \%$ \\
\hline Jumlah & & $\mathbf{2 2 9}$ & $\mathbf{1 0 0}$ \\
\hline
\end{tabular}

Dari tabel di atas diketahui bahwa mayoritas dari subjek pada aspek blame dari skala mental blocking berada pada tingkat sedang. Menyalahkan diri sendiri dan orang lain atau lingkungan dalam setiap keputusan yang mereka ambil pada kegiatan promosi menjadi hal yang tidak terhindarkan. Hal ini bisa berdampak pada keputusan promosi yang akan mereka lakukan berikutnya.

Tabel 9: Distribusi Frekuensi Mental Blocking pada aspek Excuse

\begin{tabular}{cccc}
\hline $\begin{array}{c}\text { Tingkat Mental } \\
\text { Blocking }\end{array}$ & Indikator & N & Persentase (\%) \\
\hline Rendah & $6-8$ & 20 & $8.73 \%$ \\
Sedang & $9-12$ & 188 & $82.10 \%$ \\
Tinggi & $13-15$ & 21 & $9.17 \%$ \\
\hline Jumlah & & $\mathbf{2 2 9}$ & $\mathbf{1 0 0}$ \\
\hline
\end{tabular}

Pencarian alasan dari setiap tindakan kegiatan promosi yang dilakukan oleh responden dalam peneltian ini berada di tingkatan sedang dengan angka sebaran sebanyak $82.10 \%$ dari keseluruhan total responden. Artinya responden masih ada potensi untuk pencarian alasan dari setiap kegagalan dari kegiatan promosi yang mereka lakukan.

Tabel 10: Distribusi Frekuensi Mental Blocking pada aspek Justified

\begin{tabular}{cccc}
\hline $\begin{array}{c}\text { Tingkat Mental } \\
\text { Blocking }\end{array}$ & Indikator & N & Persentase (\%) \\
\hline Rendah & $5-6$ & 59 & $25.76 \%$ \\
Sedang & $7-8$ & 141 & $61.57 \%$ \\
Tinggi & $9-10$ & 29 & $12.67 \%$ \\
\hline Jumlah & & $\mathbf{2 2 9}$ & $\mathbf{1 0 0}$ \\
\hline
\end{tabular}


Pembenaran akan kegagalan dari kegiatan promosi yang dilakukan oleh respoden pada penelitian ini berada pada tingkatan yang sedang. Dapat diartikan bahwa mayoritas atau $61.57 \%$ dari responden tersebut mempunyai potensi dalam pembenaran dari apa yang mereka yakini yang merupakan penyebab kegagalan dari kegiatan promosi usaha mereka.

Tabel 11: Distribusi Frekuensi Mental Blocking pada aspek Prestige

\begin{tabular}{cccc}
\hline $\begin{array}{c}\text { Tingkat Mental } \\
\text { Blocking }\end{array}$ & Indikator & N & Persentase (\%) \\
\hline Rendah & $5-8$ & 163 & $71.18 \%$ \\
Sedang & $9-12$ & 55 & $24.02 \%$ \\
Tinggi & $13-15$ & 11 & $4.80 \%$ \\
\hline Jumlah & & $\mathbf{2 2 9}$ & $\mathbf{1 0 0}$ \\
\hline
\end{tabular}

Para wanita pelaku usaha yang menjadi responden dalam kegiatan penelitian ini tidak memikirkan gengsi dalam melakukan kegiatan promosi usaha. Sebanyak $71.18 \%$ responden berada pada tingkatan rendah dalam aspek prestige.

Tabel 12: Distribusi Frekuensi Mental Blocking pada aspek Lazy

\begin{tabular}{cccc}
\hline $\begin{array}{c}\text { Tingkat Mental } \\
\text { Blocking }\end{array}$ & Indikator & N & Persentase (\%) \\
\hline Rendah & $5-8$ & 97 & $42.36 \%$ \\
Sedang & $9-12$ & 113 & $49.34 \%$ \\
Tinggi & $13-15$ & 19 & $8.30 \%$ \\
\hline Jumlah & & $\mathbf{2 2 9}$ & $\mathbf{1 0 0}$ \\
\hline
\end{tabular}

Tingkat kemalasan dari responden dalam melakukan kegiatan promosi berada pada level sedang sebanyak $49.43 \%$. Angka ini hampir sama dengan level rendah. Ini membuktikan bahwa para wanita pelaku usaha malas untuk memikirkan dan melakukan kegiatan promosi usaha mereka.

Tabel 13: Distribusi Frekuensi Mental Blocking pada aspek Afraid

\begin{tabular}{cccc}
\hline $\begin{array}{c}\text { Tingkat Mental } \\
\text { Blocking }\end{array}$ & Indikator & N & Persentase (\%) \\
\hline Rendah & $6-8$ & 144 & $62.88 \%$ \\
Sedang & $9-11$ & 48 & $20.96 \%$ \\
Tinggi & 12 & 37 & $16.16 \%$ \\
\hline Jumlah & & $\mathbf{2 2 9}$ & $\mathbf{1 0 0}$ \\
\hline
\end{tabular}

Dari tabel di atas diketahui bahwa mayoritas dari subjek pada aspek afraid dari skala mental blocking berada pada tingkat rendah. Rendahnya rasa takut akan kegagalan tidak mempengaruhi para wanita pelaku usaha dalam kegiatan promosi mereka.

Tabel 14: Distribusi Frekuensi Mental Blocking pada aspek Waiting

\begin{tabular}{cccc}
\hline $\begin{array}{c}\text { Tingkat Mental } \\
\text { Blocking }\end{array}$ & Indikator & N & Persentase (\%) \\
\hline Rendah & $4-6$ & 172 & $75.11 \%$ \\
Sedang & $7-8$ & 46 & $20.09 \%$ \\
Tinggi & $9-10$ & 11 & $4.80 \%$ \\
\hline Jumlah & & $\mathbf{2 2 9}$ & $\mathbf{1 0 0}$ \\
\hline
\end{tabular}


Para responden tidak membutuhkan waktu yang lama untuk segera melakukan kegiatan promosi. Spontanitas dalam kegiatan promosi yang mereka lakukan dibuktikan dengan tingkat yang rendah dalam aspek waiting sebanyak $75.11 \%$.

Tabel 15: Distribusi Frekuensi Mental Blocking pada aspek Uncofident

\begin{tabular}{cccc}
\hline $\begin{array}{c}\text { Tingkat Mental } \\
\text { Blocking }\end{array}$ & Indikator & N & Persentase (\%) \\
\hline Rendah & $6-8$ & 134 & $58.52 \%$ \\
Sedang & $9-12$ & 87 & $37.99 \%$ \\
Tinggi & $13-15$ & 8 & $3.49 \%$ \\
\hline Jumlah & & $\mathbf{2 2 9}$ & $\mathbf{1 0 0}$ \\
\hline
\end{tabular}

Kegiatan promosi yang mereka lakukan selalu diiringi dengan tingkat kepercayaan akan kemampuan diri sendiri yang cukup bagus. Mayoritas responden berada pada level rendah dalam aspek ini. Persentase level rendah dalam aspek unconfident mereka berada pada angka $58.52 \%$.

Tabel 16: Distribusi Frekuensi Mental Blocking pada aspek Bad Suspicion

\begin{tabular}{cccc}
\hline $\begin{array}{c}\text { Tingkat Mental } \\
\text { Blocking }\end{array}$ & Indikator & N & Persentase (\%) \\
\hline Rendah & $6-9$ & 158 & $69.00 \%$ \\
Sedang & $10-12$ & 48 & $20.96 \%$ \\
Tinggi & $13-15$ & 23 & $10.04 \%$ \\
\hline Jumlah & & $\mathbf{2 2 9}$ & $\mathbf{1 0 0}$ \\
\hline
\end{tabular}

Prasangka buruk akan kegagalan kegiatan promosi yang dilakukan oleh para responden mayoritas berada pada level rendah dengan persentase sebanyak $69 \%$. Hal ini dapat diartikan bahwa mayoritas responden kurang memiliki prasangka buruk dalam kegiatan promosi usaha mereka. Dalam artian lain dapat diterjemahkan dari tabel distribusi diatas adalah adanya indikasi bahwa para responden mayoritas optimis akan keberhasilan dari kegiatan promosi usaha mereka.

\subsection{Hasil Analisa Korelasi dan uji hipotesa}

Tabel 17: Uji Hipotesis

\section{Coefficients $^{\mathrm{a}}$}

\begin{tabular}{|c|c|c|c|c|c|c|}
\hline \multirow[b]{2}{*}{ Model } & \multicolumn{3}{|c|}{\begin{tabular}{|c|l|} 
Unstandardized & Standardized \\
Coefficients & Coefficients
\end{tabular}} & \multirow[b]{2}{*}{$\mathrm{T}$} & \multirow[b]{2}{*}{ Sig. } & \multirow[b]{2}{*}{ Kesimpulan } \\
\hline & B & $\begin{array}{l}\text { Std. } \\
\text { Error }\end{array}$ & Beta & & & \\
\hline $\begin{array}{l}1 \text { (Constant) } \\
\text { Mblock }\end{array}$ & $\begin{array}{r}88.058 \\
-.032\end{array}$ & $\begin{array}{r}2.636 \\
.034\end{array}$ & -.062 & $\begin{array}{r}33.403 \\
-.936\end{array}$ & $\begin{array}{l}.000 \\
.350\end{array}$ & $\begin{array}{l}\text { Nilai signifikansi } 0.350 \text { lebih besar } \\
\text { dari } 0.05 \text { artinya tidak ada pengaruh } \\
\text { yang signifikan mental block dengan } \\
\text { berpikir analitis dan kritis }\end{array}$ \\
\hline
\end{tabular}

a. Dependent Variable: Ankrit

Dalam uji hipotesis didapatkan informasi bahwa hubungan antara mental blocking dengan berpikir analitis dan kritis bersifat negatif sebesar - 0.62 namun tidak ada memiliki pengaruh yang signifikan. Artinya adalah semakin tinggi tingkat mental blocking yang dialami oleh para 
responden maka semakin rendah tingkat berpikir kritis dan analitis yang mereka miliki akan tetapi pengaruhnya tidak begitu signifikan dalam penelitian ini. Dengan kata lain, mental blocking diantaranya ketakukan terhadap kegagalan, merumuskan sebuah permasalahan terlalu sempit, dan tertekan akan tidak kunjung berhasil yang dialami oleh responden untuk penelitian ini tidak memiliki pengaruh yang signifikan terhadap kemampuan mereka dalam berpikir kritis dan analitis.

Tabel 18: Uji Analisis Regresi Linear Sederhana

\begin{tabular}{|l|r|r|r|r|l|}
\hline \multicolumn{1}{|c|}{ Model Summary } \\
\hline Model & \multicolumn{1}{|c|}{$\mathrm{R}$} & R Square & $\begin{array}{c}\text { Adjusted R } \\
\text { Square }\end{array}$ & $\begin{array}{l}\text { Std. Error of } \\
\text { the Estimate }\end{array}$ & \multicolumn{1}{c|}{ Kesimpulan } \\
\hline 1 & $.062^{\mathrm{a}}$ & .004 & -.001 & 5.72477 & $\begin{array}{l}\text { Mental block berpengaruh negatif } \\
\text { terhadap analisis berpikir analitis dan } \\
\text { kritis dengan total pengaruh sebesar } \\
4 \text { persen }\end{array}$ \\
\hline
\end{tabular}

a. Predictors: (Constant), Mblock

Dari hasil penelitian dapat diambil kesimpulan bahwa hubungan antara mental blocking dengan berpikir analitis-kritis bersifat negatif dan memberikan pengaruh sebesar 4 persen dalam berpikir analitis-kritis. Minimnya pengaruh mental blocking sebesar 4 persen ini disebabkan karena dalam distribusi skoring pada mental blocking mayoritas berada di tingkat rendah dan distribusi skoring pada berpikir analitis-kritis mayoritas berada pada tingkat cukup. Faktor lain yang diduga ikut mempengaruhi minimnya kontribusi antara lain terlalu banyaknya butir item yang harus diisi oleh subjek sehingga ikut mempengaruhi objektifitas dalam pengisian skala tersebut. Dilihat dari distribusi skoring masing-masing aspek dalam skala, pada umumnya lebih banyak berada tingkat rendah dan cukup (untuk skala mental blocking) dan tingkat rendahtinggi (untuk skala berpikir kritis analitis-kritis).

\section{Kesimpulan}

Berdasarkan hasil penelitian dan pembahasan apakah ada pengaruh antara mental blocking terhadap berpikir analitis dan kritis dalam kegiatan promosi yang dilakukan oleh wanita pelaku usaha mikro kecil didapat kesimpulan bahwa hubungan antara mental blocking dengan berpikir analitis-kritis kurang signifikan dan memberikan pengaruh sebesar 4 persen. Minimnya pengaruh mental bloking disebabkan karena dalam distribusi skoring pada mental blocking mayoritas berada di tingkat rendah dan distribusi skoring pada berpikir analitis-kritis mayoritas berada pada tingkat cukup sehingga disarankan untuk peneliti berikutnya untuk menggunakan skala yang lebih ringkas dan mencari aspek lain yang mempengaruhi berpikir kritis-analitis.

Dari penelitian ini dapat diambil beberapa hal yang menjadi kekurangan yang dapat diperbaiki untuk penelitian berikut, yakni:

1. Jumlah skala terlalu banyak dan waktu pengisian skala yang lama

2. Teknik pengumpulan data penelitian terbatas dalam bentuk kuesioner (angket) dengan subjektifitas responden sehingga kejujuran responden adalah kunci pokok dalam kebenaran keadaan diri responden.

3. Kondisi dan situasi yang tidak memungkinkan terkait pandemi covid 19 


\section{Daftar Pustaka}

[1] Hapsari, Hakim, dan Soeaidy. 2014. Pengaruh Pertumbuhan Usaha Kecil Menengah (UKM) terhadap Pertumbuhan Ekonomi Daerah (Studi di Pemerintah Kota Batu). Jurnal Wacana-Vol. 17, No. 2. Jurusan Administrasi Publik, Fakultas Ilmu Administrasi, Universitas Brawijaya

[2] www.bps.go.id

[3] www.diskop.padang.go.id

[4] Susanti dan Dimas, 2018, Strategi Branding dalam Membangun Ekuitas Merek UMKM (Studi Kasus: Pusat Oleh - Oleh Kota Padang), IKRAITH - EKONOMIKA, Volume 1, Nomor 2, November 2018, Universitas Persada Indonesia YAI.

[5] International Finance Corporation, 2016, Studi Penelitian Pasar: UKM yang dimiliki wanita di Indonesia: Kesempatan Emas untuk Institusi Keuangan Lokal. Frankfurt School of Finance \& Management, Sonnemannstrasse 9-1160314 Frankfurt a.M.

[6] Fitriyani, K., 2016, Konseling Krisis dalam menangani mental block pada korban penyalahgunaan NAPZA di Panti Sosial Pamardi Yogyakarta, Program Studi Bimbingan Konseling Islam Fakultas Dakwah dan Komunikasi, Universitas Islam Nasional Sunan Kalijaga, Yogyakarta.

[7] Pattinson, E.M. and Cotterill, S.T., 2017, Barriers and facilitators to overcoming mental block in springboard and high-board diving, Journal of Qualitative Research in Sports Studies Volume 11, Issue 1, December 2017.

[8] Setiawati, R., 2018, Peningkatan Kemampuan Analisis Transaksi Dalam Menyusun Jurnal Dengan Model Problem Based Learning Melalui Pengamatan BT/ BK, Jurnal Inopendas Jurnal Ilmiah Kependidikan ISSN 2615-5443 Vol. 1 No. 1, Februari 2018.

[9] Adji, S.S. dan Harjanti, S., 2011, Laporan Penelitian: Analisis Kemampuan Berfikir Kritis Pada Aktivitas Tutorial On-Line, Universitas Terbuka.

[10] Pratiwi, A.J., Mirza A., Nursangaji A., 2015, Kemampuan Berpikir Kritis Aspek Analysis Siswa Di Sekolah Menengah Atas, Jurnal Edukasi Volume I No. 2 tahun 2015.

[11] Sukriadi, Kartono, dan Wiyanto, 2015, Analisis Hasil Penilaian Diagnostik Kemampuan Berpikirkritis Matematis Siswa Dalam Pembelajaran Pmri Berdasarkan Tingkat Kecerdasan Emosional, Journal of Mathematics Education Research volume 4.

[12] Kotler, P. and Armstrong, G., 2016. Principles of Marketing. 16th ed. Edinburgh Gate, Essex: Pearson Education Limited.

[13] Kotler, P. and K.L. Keller. 2012. Marketing Management. 14th ed. Upper Saddle River. NJ: Prentice Hall.

[14] Sugiyono. (2014). Metode Penelitian Pendidikan Pendekatan Kuantitatif, Kualitatif dan R\&D. Bandung: Alfabeta.

[15] Sugiyono. (2014). Metode Penelitian Pendidikan Pendekatan Kuantitatif, Kualitatif dan R\&D. Bandung: Alfabeta.

[16] Sevilla, ConsuelloG. Et al. 2007. Research Methods. Rex Printing Company, Quezon City

[17] Undang - Undang Republik Indonesia Nomor 20 Tahun 2008. Usaha Mikro, Kecil, dan Menengah. 4 Juli 2008. Lembaran Negara Republik Indonesia Tahun 2008 Nomor 93. Jakarta.

[18] Mustafa, Abdulah Indra. 2014. Pengaruh Berpikir Kritis, Kecakapan Sosial, Dan Kemampuan Metakognitif Terhadap Motivasi Bertechnopreneurship Siswa Kelas Xii Program Keahlian Elektronika Industri Smk Negeri 3 Wonosari. Program Studi Pendidikan Teknik Elektro Jurusan Pendidikan Teknik Elektro Fakultas Teknik Universitas Negeri Yogyakarta

[19] Fitriyani, K., 2016, Konseling Krisis dalam menangani mental block pada korban penyalahgunaan NAPZA di Panti Sosial Pamardi Yogyakarta, Program Studi Bimbingan Konseling Islam Fakultas Dakwah dan Komunikasi, Universitas Islam Nasional Sunan Kalijaga, Yogyakarta. 